Articles from 2013 and after

are now only accessible on

the Chicago Journals website at

JOURNALS.UCHICAGO.EOU

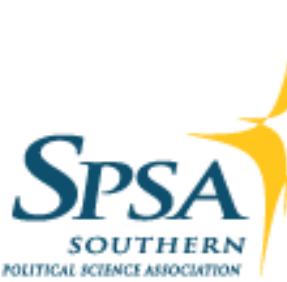

Congressional Appropriations and the Electoral Connection

Author(s): D. Roderick Kiewiet and Mathew D. McCubbins

Source: The Journal of Politics, Vol. 47, No. 1 (Feb., 1985), pp. 59-82

Published by: University of Chicago Press on behalf of the Southern Political Science

Association

Stable URL: http://www.jstor.org/stable/2131066

Accessed: 18-02-2016 21:41 UTC

Your use of the JSTOR archive indicates your acceptance of the Terms \& Conditions of Use, available at http://www.jstor.org/page/ info/about/policies/terms.jsp

JSTOR is a not-for-profit service that helps scholars, researchers, and students discover, use, and build upon a wide range of content in a trusted digital archive. We use information technology and tools to increase productivity and facilitate new forms of scholarship. For more information about JSTOR, please contact support@jstor.org. 


\title{
Congressional Appropriations and the Electoral Connection
}

\author{
D. Roderick Kiewiet \\ California Institute of Technology \\ Mathew D. McCubbins \\ University of Texas at Austin
}

\begin{abstract}
Congressional scholars have frequently reported dramatic shifts in the mood of Congress toward federal spending. In seeking to explain these fluctuations in congressional moods, we develop and estimate an "electoral connection" model of the congressional appropriations process. In this model appropriations decisions are seen to be the product of the responses of reelection-seeking members of Congress to the key political and economic variables in their environment.

Analyses of appropriations for thirty-seven federal agencies between fiscal years 1948 and 1979 provided broad support for our hypotheses. First, Congress has been more generous in awarding appropriations during election years than during nonelection years. Appropriations are also influenced by prevailing economic conditions. Higher unemployment leads to higher levels of appropriations, especially for public works agencies. Conversely, Congress has responded to high rates of inflation by holding down appropriations. And as in other areas of public policy, parties matter: the larger the percentage of Democrats in the House of Representatives, the more funds agencies were appropriated. The strong empirical support garnered by our electoral connection model thus adds some much needed balance to the conventional incrementalist view of federal government spending.
\end{abstract}

\section{INTRODUCTION}

$\mathrm{I}_{\mathrm{n}}$ The Power of the Purse, Fenno (1966) described Congress as usually being in an "economy mood." During the eighteen years Fenno observed

* This paper has benefited greatly from the advice and assistance of Bruce Cain. Jeff Dubin, David Grether, Richard McKelvey, Doug Rivers, and Quong Vuong provided econometric advice. We would also like to thank Bob Bates, Richard Fenno, John Ferejohn, Morris Fiorina, Ed Green, Peter Gourevitch, Mark Kamlet, Keith Krehbiel, Allan Meltzer, Terry Moe, Roger Noll, Ben Page, Howard Rosenthal, Alan Schwartz, and the anonymous referees for their valuable comments and criticisms. 
appropriations politics in Congress, the virtue of budgetary frugality was exemplified by the House Appropriations Committee and magnified by the powerful role this committee played. Sometimes, though, a different mood would overtake Congress. Hesitating to call it a "spending mood," Fenno described it instead as a more "permissive" attitude toward spending. During such periods Congress would become anxious to avoid the pitfalls of false economy and would strive to make sure that authorized programs received adequate levels of funding.

Much has changed since the period of Fenno's analysis. Entitlement programs have experienced tremendous growth. Standing budget committees oversee the complex routine of the new budgetary process, while the appropriations committees, according to Schick (1980), have become "subdued guardians." Nevertheless, shifts in congressional attitudes toward federal spending still occur. In 1981 the Reagan administration won congressional approval for substantial cuts in the budgets of several domestic agencies and programs. Similar efforts since then, however, have been much less successful.

What accounts for these shifts in the mood of Congress toward spending? Unfortunately, previous theory and research on budgetary politics provide us with little guidance as to what the causes of these fluctuations might be. Inspired by organizational theories of satisficing behavior and bounded rationality (Simon, 1957; Lindblom, 1961), research on the budgetary process has stressed the importance of standard bureaucratic operating procedures and programmatic inertia (Wildavsky, 1964; Davis, Dempster, and Wildavsky, 1966). This work has been one of the most fruitful research programs in political science, yielding valuable insights into the internal dynamics of budgetary decision making. It has, however, focused relatively little attention upon the influence of Congress and congressional politics on the budgetary process. In this paper we develop and test an empirical model of the congressional appropriations process which is broadly informed by the "electoral connection" view of legislative behavior (Mayhew, 1974; Fiorina, 1977). For present purposes the key feature of this view is that members of Congress, desirous of reelection, respond to the demands and exigencies of their environment in such a way as to maximize the probability of this happy occurrence.

The major contribution of this study will not be the discovery of previously unsuspected sources of influence upon appropriations decisions; Fenno and others have suggested what many of these variables might be. The question of how strongly major political and economic variables affect important policy outputs such as appropriations is, however, very much at issue in current political research. Most important, empirical support for our electoral connection model will add some much needed balance to the conventional incrementalist view of 
budgetary politics, a view which has tended to ignore the influence of external political demands upon government spending decisions.

\section{An Electoral Connection Model of Congressional Appropriations}

In developing our electoral connection model of the congressional appropriations process, we make a number of assumptions about voters, members of Congress, and congressional policymaking. These assumptions, which have undergirded a vast amount of congressional scholarship over the last decade or so, all grow out of the basic premise of Mayhew's (1974) analysis - that the structure and behavior of Congress can best be understood as the consequences of reelection seeking by individual members of Congress. ${ }^{1}$

The appropriations which are awarded to agencies of the federal government buy goods and services which benefit various groups in society. Some agencies benefit groups which are quite broad and diffuse; most noncriminals, for instance, probably benefit from the activities of the Federal Bureau of Investigation. Other agencies, of course, benefit extremely narrow clientele, concentrated in either specific geographic locations (beneficiaries of the Bureau of Reclamation, for example) or defined by specific social or demographic characteristics (such as the aged or disabled). In general, concentrated, narrowly defined groups will be better able to overcome the collective action problems which impede organizing and lobbying (Olson, 1965).

These various groups in society base their support of incumbents at least in part upon retrospective evaluations of the levels of benefits conferred on them by federal programs. The extensive literature on retrospective voting has generated a great deal of evidence that voters have fairly large positive discount factors and that they are also "myopic"; that is, they discount the future costs of present benefits (Nordhaus, 1975; Fair, 1978; Kiewiet, 1983). We will thus assume this to be true of voters and contributors regardless of the size and nature of the groups with which they are associated.

Members of Congress, desirous of reelection, seek to maximize the elec-

${ }^{1}$ As Bueno de Mesquita (1981) points out, any empirical analysis of a collectivity (committees, legislatures, nations, etc.) must address the generic problem of preference aggregation by assuming either that the collectivity chooses in accordance with the preferences of a dictator or those of representative individuals (the median voter, for example). We adopt the latter, assuming that the appropriations decisions made by Congress are nonnegatively responsive to the preferences of individual legislators. The essence of this assumption is that the legislative process is not perverse; that is, if one or more members of Congress prefer to increase spending for some agency, ceteris paribus, the collective choice will not be to decrease the agency's funding. 
toral support (campaign contributions, votes, etc.) they receive from the various beneficiaries of government goods and services. The level of support received from each clientele group is assumed to be a nondecreasing function of the appropriations awarded to the agency which benefits them. We also assume, however, that members of Congress experience declining marginal returns in electoral support from the appropriations awarded to each agency. In order to maximize their reelection prospects, incumbents will thus choose appropriation levels which equate marginal returns in electoral support across federal agencies. This will result, other things being equal, in a disproportionate share of benefits (relative to the size of their membership) flowing to those groups which are better able to organize, make campaign contributions, and deliver votes.

In contrast, the costs of these goods and services provided by agencies of the federal government are quite diffuse, as they are financed out of general revenue collected from all U.S. taxpayers. To be sure, members of Congress may make tradeoffs between the campaign resources garnered through their support of various federal benefit programs and votes obtained by decreasing taxes. However, the fact that benefits tend to be concentrated and costs diffuse, combined with the fact that the federal government faces a "soft" budget constraint (it may and almost always does spend more than it takes in), means that appropriations decisions will not reflect the true tax costs of federal benefit programs (Wildavsky, 1975; Weingast, Shepsle, and Johnson, 1981; McCubbins and Sullivan, 1984).

Given these assumptions, then, what are the major variables which would presumably impinge upon the appropriations decisions of a legislature composed of individuals seeking to survive in this sort of political environment? Perhaps what comes most readily to mind as a source of changing congressional moods toward spending is the electoral calendar. As the salience of electoral imperatives (raising money and garnering votes) increases with the proximity of election day, incumbents will become increasingly anxious to channel government benefits to their constituents (or at least, alternatively, less anxious to cut such benefits). Such benefits, furthermore, will become politically more salient to constituents as the election nears. This tendency will be reinforced, of course, by members of Congress knowing that over time beneficiary groups discount what they have received. Maximizing the amount of electoral support earned by the flow of government goods and services thus indicates "heaping" these benefits later on in the electoral cycle (Nordhaus, 1975; Tufte, 1978). Specifically, then, we would expect Congress to be more generous in its treatment of agency budgets in election years than in nonelection years.

An electoral connection view of congressional decision making further 
suggests that the approach of election day will have a larger impact upon the appropriations of agencies which supply goods and services of a highly divisible nature. As the returns to political action increase, the incentives for particular groups to overcome their political action problems also increase. If this collective action takes the form of campaign contributions and other types of political support, then those programs which supply concentrated benefits to well-organized groups will yield incumbents a higher marginal rate of electoral support at a given level of funding than will programs which supply benefits to a wide segment of society. ${ }^{2}$

Benefits which are highly divisible in nature, then, can be directly channeled to politically important groups in incumbents' constituencies. To be sure, few members of Congress ever witness with equanimity cuts in programs which aid key interest groups in their districts. But we would expect calls for economy in these areas to fall upon deaf ears as the second session comes to a close, as such groups are the major source of the money and labor members need for their reelection campaigns. The surest beneficiaries of election-year permissiveness, furthermore, should be public works agencies, as individual members can claim full, personal credit for the jobs and dollars brought back home by public works projects (Mayhew, 1974; Fiorina, 1977).

Second, changing congressional moods toward federal spending should be a function of changing economic conditions. Voters hold those in power responsible for bad economic times; so fluctuations in the nation's economy clearly affect the outcomes of congressional elections (Kramer, 1971). The campaign decisions of both incumbents and potential challengers as well as the behavior of contributors give considerable weight to this fact of political life (Jacobson and Kernell, 1981). Fenno (1966), furthermore, believed that the 1954 and 1958 recessions helped trigger a permissive mood in those years. Also, Davis, Dempster, and Wildavsky (1974) report that the predictive power of their budget equations was often enhanced by the inclusion of assorted economic variables.

There are, of course, many plausible ways to specify how appropriations decisions respond to economic conditions; neither politicians nor macroeconomists hold a consensual view of prescriptive fiscal policy. At least some members of both groups, however, hold that governments should decrease spending in response to inflation and increase spending in response to unemployment. Insofar as high levels of government spending are perceived by voters and contributors to induce inflationary

${ }^{2}$ That the marginal rate of political support derived from appropriations is increasing in the "divisibleness" of the agency's benefits does not imply that agencies which supply relatively indivisible benefits receive no appropriations. This means only that the latter type of agencies will receive disproportionately less appropriations than their numbers would otherwise suggest. The presence of an election year simply serves to exacerbate this bias. 
pressures, we will hypothesize that Congress responds to high rates of inflation by appropriating less to government agencies. Conversely, to the extent that voters and contributors believe the Keynesian axioms, we will hypothesize that high rates of unemployment lead Congress to award higher levels of appropriations to government programs and agencies.

As was the case with election-year considerations, high levels of unemployment should make reelection-minded members of Congress even more solicitous about funding for agencies which channel benefits directly to their districts - especially job-creating public works projects for which they can claim full credit. The initiation of new public works projects, the acceleration of work on projects in progress, or a sizable increase in the number of federal dollars flowing to important economic interests in their districts provides at least some shelter from the ill political climate engendered by high rates of joblessness. Bad times, by enlarging the differences in marginal returns in electoral support from appropriations for programs which supply highly divisible benefits vis-à-vis those which do not, serve to exacerbate the chronic institutional bias of the Congress toward providing divisible, constituency-oriented benefits (Ferejohn, 1974; Arnold, 1979; Shepsle, 1983; Shepsle and Weingast, 1984). We will thus hypothesize that those agencies which supply such benefits, especially public works agencies, will be treated more generously in periods of high unemployment than line agencies whose benefits are much less divisible in nature.

We might expect, similarly, that inflation-induced budgetary pressures will take a relatively larger slice from the appropriations of line agencies which supply largely indivisible benefits than from other agencies, including public works, whose benefits are relatively divisible. This may not be the case, however, as inflation and unemployment have very different distributional consequences. It is well known how the costs of unemployment are distributed; those whose employment opportunities are most severely diminished by a recession tend to be working class, in construction and other credit-sensitive industries, younger, and minority group members. It is they, conversely, who are also the beneficiaries of job-creating federal programs. The net distributional consequences of inflation, in contrast, are much smaller and far less systematic (Piachaud, 1978). This lack of distributional consequences may mean that a high inflation rate does not alter the relative attractiveness of providing benefits of a divisible nature versus those which are more indivisible.

Another political variable which we would expect to exert a clear, continuous influence upon appropriations decisions is party politics; in general, Democrats prefer to spend more than Republicans. In the years during the Truman administration in which they controlled Congress, the Republicans slashed agency estimates, especially in the areas of labor pro- 
grams and public power (Fenno, 1966). Democratic Congresses, in contrast, generally cut much less from OMB estimates and often appropriated more than OMB had requested. We will hypothesize, then, that as the percentage of Democrats in Congress increases, so does the amount Congress appropriates to federal agencies (all else constant).

At first glance this hypothesis would seem to run counter to the spirit of an electoral connection model. By this view incumbents' reelection prospects depend ultimately upon their ability to satisfy the demands of their constituency. The legislative behavior literature, though, has traditionally posed "party" and "constituency" as alternative, often contradictory sources of influence upon legislators. It is our sense, however, that party and constituency pressures coincide far more often than not. While it is true that congressional districts represented by Democrats often closely resemble other districts which have Republican representatives, we are confident that the reelection constituencies of Democratic and Republican legislators do reliably differ (Fiorina, 1974; Fenno, 1978; Poole and Rosenthal, 1983). The hypothesized tendency for Democrats to support higher levels of spending than Republicans can thus be attributed at least in part to differences in their constituencies.

Still, at certain junctures adherence to party policy priorities will run counter to the electoral imperative of procuring benefits for one's district. Indeed, it is frequently argued that differences between Republicans and Democrats melt away when funding for agencies which supply highly divisible, constituency-oriented benefits is considered. Shepsle (1983), for instance, quotes David Stockman's statement: "There is no such thing as a fiscal conservative when it comes to his district or his subcommittee." We will hypothesize, then, that in such cases constituency wins out over party, and that appropriations for public works and other constituencyoriented agencies are relatively insensitive to the partisan composition of Congress.

Appropriations decisions, of course, are not solely in the hands of Congress; federal funding levels reflect the preferences of the president as well. Interaction between Congress and the president resembles a bilateral bargaining game, which, for a number of reasons, should be a cooperative one (Kiewiet and McCubbins, 1984). There should thus exist a strong, positive relationship between what the OMB requests and what Congress appropriates. First and foremost, OMB estimates reflect the preferences of presidents; Congress must take this into account, as presidents can always veto appropriations bills which they find objectionable. It is also true, though, that if the OMB (which we assume to be agent of the president) is to maximize its influence over the budgetary fortunes of executive agencies it must anticipate Congress's response to the estimates it submits. Finally, it is likely that the executive responds to 
many of the same exogenous political and economic variables which influence Congress. For these reasons, then, a satisfactory model of congressional appropriations decisions must not incorporate OMB estimates as another exogenous variable. The actions of these institutions must instead be modeled as endogenous to each other.

Inclusion of the OMB budget estimate into our model introduces an additional complication which arises from the transition from one administration to another. A few days before leaving office in January 1977, for example, Jerry Ford submitted budget requests to Congress for fiscal year 1978. The president who had to approve fiscal 1978 appropriations bills, however, was Jimmy Carter. The same situation occurred in 1961 (fiscal year 1962), while the reverse (a Republican succeeding a Democrat) occurred in 1953 and 1969 (fiscal years 1954 and 1970). If the preferences of the president reflect his party and Congress is solicitous of his preferences, the transition from a Democratic to a Republican administration should result, ceteris paribus, in Congress awarding agencies lower levels of appropriations than if a Democrat had remained in office. Transition to a Democratic administration, conversely, should result in federal agencies receiving more money than if the Republicans had retained control of the White House. Our model should thus include a term which registers the transition from an administration of one party to that of another. Such a variable will serve as an additional measure of presidential influence upon congressional decision making.

\section{DAta}

The electoral connection model we have developed implies that election-year pressures and unemployment will have a larger impact upon appropriations for public works agencies and other agencies which supply highly divisible, constituency-oriented benefits than upon appropriations for agencies whose benefits are relatively indivisible in nature. The influence of party policy priorities-and perhaps inflation-should be smaller for the former type of agencies. We therefore collected OMB estimates and final appropriations figures from fiscal years 1948 to 1979 for four public works agencies, fifteen other constituency-oriented agencies, and eighteen agencies which provide largely indivisible benefits. Both sets of figures were reported in various regular annual appropriations acts. Many agencies often receive additional funding in supplemental and deficiencies acts. These figures are almost always quite small, however, and including them in the agencies' yearly appropriations totals would have little effect upon the results of this analysis. ${ }^{3}$

${ }^{3}$ In a handful of instances agency appropriations which customarily appeared in a regular 
The thirty-seven agencies listed in table 1 contain all but three of the thirty-six agencies examined by Fenno. ${ }^{4}$ Agencies were assigned to one category or the other on the basis of the description of their activities contained in the United States Government Manual and other sources. As Fenno noted, most of the agencies which supply large proportions of divisible, constituency-oriented benefits are either in the Agriculture and Interior departments or are considered in the Public Works Bill. ${ }^{5}$ In many cases the placement of an agency in the first category is also corroborated by the scholarly attention it has received in the "subgovernment" literature that documents the symbiotic relationship between a particular congressional committee, agency, and interest group. Because the only public works agency in Fenno's sample was the Bureau of Reclamation, we augmented this subsample by including data from three other agencies which sponsor construction projects-the Corps of Engineers, Military Construction, and the Economic Development Administration. The only other addition to Fenno's sample was the National Aeronautics and Space Administration, whose activities are concentrated in a number of specific locations.

In contrast to agencies in the first category, agencies in the second perform services which are not directed toward specific interest groups, locations, or segments of the population. Most are engaged in routine governmental operations, for example, law enforcement, revenue collection, and minting currency. The others promulgate standards or gather scientific, economic, or demographic data.

A taxonomy as simple as this one, of course, blurs over many important distinctions. Benefits supplied by some agencies in the first column accrue in a more direct fashion to a specific group than do the benefits of

appropriations act appeared instead in a subsequent supplemental act. In such cases these appropriations were counted toward the agency's funding for that year. In all other cases the funds appropriated in deficiency and supplemental acts were for line items already covered in the regular annual act. As stated above, these figures were almost always very small, and they were not included in the following analyses.

${ }^{4}$ Our rationale for sticking as closely as possible to the Fenno sample was to insure that the findings of our analysis could not be attributed to our use of a highly idiosyncratic data set. The three agencies which were omitted were two divisions in the Labor Department (the Wage and Hours Division and the Women's Bureau) and the Social Security Administration. The first two were dropped because of their extremely small size, while the Social Security Administration was dropped because of the frequent incomparability of figures reported from one year to the next.

${ }^{5}$ The only agency in the Interior Department not included in this category was the Geological Survey. Programs and agencies which were included but which are covered in funding bills other than those concerning Agriculture, Interior, or Public Works bills were Military Construction, the Economic Development Administration, the National Aeronautics and Space Administration, the Vocational Rehabilitation Service, the Public Health Service, and the Office of Education. 


\section{TABLE 1}

Agencies Categorized by the Nature of Their Benefits

Agencies Supplying Divisible, Constituency-Oriented Beneftrs

\section{Extension Service}

Farmers Home Administration

Rural Electrification Admin.

Soil Conservation Service

Forest Service

Bureau of Land Management

National Park Service

Bureau of Indian Affairs

Fish and Wildlife Service (1948-71)

Bureau of Mines (1948-74)

Bonneville Power Admin. (1949-75)

Office of Education

Public Health Service (1948-69)

Office of Voc. Rehab. (1948-68)

NASA (1960-79)

Public Works Agencies

Bureau of Reclamation

Corps of Engineers

Military Construction (1960-79)

Economic Dev. Admin. (1966-79)
Agencies Supplying Relatively

INDIVISIBLE BENEFITS

Food and Drug Administration

Patent Office

Weather Bureau (1948-66)

Coast and Geodetic Survey (1948-66)

Geological Survey

Census Bureau

Federal Bureau of Investigation

Imm. and Naturalization Service

Federal Prison System

Bureau of Narcotics (1948-69)

Bureau of Customs

Bureau of the Public Debt

Secret Service

Internal Revenue Service

Bureau of the Mint

Bureau of Standards (1948-73)

Bureau of Labor Statistics

Bureau of Labor Standards (1948-68)

Note: Most agencies in this sample existed continuously from FY1948 through FY1979. If they did not, the years in which they were in existence are reported.

others. These agencies also differ in how geographically concentrated their beneficiaries are; consumers of electricity generated by the Bonneville Power Administration, for example, reside in several congressional districts in the Northwest, while the Office of Education has funded school construction in virtually every district in the country. It is also true that the character of an agency can change over time; the Sagebrush Rebellion, for example, suggests that the Bureau of Land Management is no longer as completely beholden to local ranching interests as McConnell's (1966) study had indicated.

There were also a few agencies which did not fit as cleanly into the second category as we would have liked. To be sure, a purely indivisible public good exists only in theory - some groups or individuals will always consume more of a public good than others. Our strongest reservations, however, concerned the Bureau of the Mint and the Federal Prison System, which operate facilities in a fairly small number of specific locations and which were occasionally appropriated relatively large amounts 
of funds for new construction. It is also the case that advertisers, developers, and similar enterprises have come to make heavy use of Census Bureau data and that the Customs Service has recently won favor from domestic clothing and appliance manufacturers for its enforcement of antidumping and counterfeit label statutes. For the most part, however, the benefits provided by these agencies were not, during the time period under consideration, targeted at a particular interest group or segment of the population. On the whole, then, the agencies listed in table 1 reside comfortably in the category to which they have been assigned.

\section{Estimation}

Before proceeding there are some econometric issues which must be addressed. First, as indicated earlier, OMB requests must be modeled as an endogenous variable. This requires estimation of the model by means of two-stage least squares regression or some similar technique. ${ }^{6}$ The next issue concerns the way in which the endogenous appropriations and OMB request variables are to be specified. Although we did not touch upon this point earlier, we feel it only makes sense to express our hypotheses in terms of real levels of funding. We thus converted the nominal requests and appropriations figures into constant (1972) dollars (deflation was based upon the Implicit Price Deflator for Federal Government Goods and Services). Second, virtually all accounts of the appropriations process stress that key decision makers within both branches consider proposed budgetary figures primarily in terms of the changes such figures represent over the previous fiscal year (Fenno, 1966; Wildavsky, 1974; Berman, 1979). We therefore divided the real dollar OMB estimate and appropriations figures for each agency by the real dollar appropriations it received in the previous fiscal year, producing the two endogenous terms to be used in the analysis.

Probably the most serious estimation problem derives from the small number of observations for each agency; the full time series is only thirtytwo years long, and for some agencies there are many fewer observations than that. Pooling data across the thirty-seven agencies in the sample thus presents important advantages. We not only gain statistical leverage but also simplify the analysis, as each major hypothesis can be

${ }^{8}$ In developing their original models Davis, Dempster, and Wildavsky (1966) recognized the interdependence between the actions of Congress and the $\mathrm{OMB}$, and explicitly modeled the budgetary process as a simultaneous system (p. 536). They justified their use of ordinary least squares by assuming that the system was recursive, i.e., that the covariance matrix was diagonal. It is generally the case, however, that the error terms in multi-equation models incorporate the effects of a common set of excluded explanatory variables. In such situations ordinary least squares estimates will be biased. Consistent estimates can be obtained with instrumental variables techniques such as those used in this paper. 
tested by estimating a single coefficient. There are, however, some caveats to be observed with this procedure. The first is cross-sectional correlation; factors which produce error in predicting appropriations for agency $i$ in year $t$ may be the same factors which produce error in predicting appropriations for agency $i$ in year $t$. The resultant correlation between error terms for the same year will bias estimates of the standard errors. It is thus important to check the degree of correlation between residuals for the various agencies. Second, the series of residuals for each separate agency should be checked for the presence of serial correlation, a problem which would reduce the efficiency of our estimates.

\section{Analysis and Results}

The hypotheses we have proposed are of two types. The first pertains to the effects of certain economic and political variables upon appropriations decisions in general, while the second concerns the differential effects of these variables upon different classes of federal agencies. As for the first set, we have hypothesized that Congress is more generous in its treatment of agency requests in election years than in nonelection years and that Congress responds to higher rates of unemployment by increasing agency appropriations, but decreases agency appropriations in response to higher rates of inflation. We also hypothesized that as the proportion of Democrats in office increases, so does the amount of funds agencies are appropriated, and that the larger the increase that an agency's OMB estimate represents over the previous year appropriations, the larger the increase Congress makes in its appropriations. Furthermore, a transition from a Republiean (Democratic) president who submitted agency budget estimates to a Democratic president results in Congress awarding higher (lower) levels of appropriations than if the Republican had remained in office. We tested these hypotheses by estimating the following equation:

$$
\begin{aligned}
\Delta \text { CONG }_{i t}=\alpha & +\beta_{1} \Delta O M B_{i t}+\beta_{2} E_{t}+\beta_{3} U_{t-1}+\beta_{4} I_{t-1} \\
& +\beta_{5} D E M_{t}+\beta_{6} \text { TRANS }_{t}+\epsilon_{i t},
\end{aligned}
$$

where:

\footnotetext{
$\alpha=$ a constant term;

$\triangle C O N G_{i t}=$ appropriations (in constant dollars) awarded by Congress to agency $i$ in fiscal year $t$ as a proportion of what the agency had received in the previous fiscal year; if an agency's appropriations in year $t$ is represented by $C O N G_{i t}$, then $\triangle C O N G_{i t}=C O N G_{i t} / C O N G_{i, t-1}$;
} 
$\triangle O M B_{i t}=$ an instrumental variables estimate for appropriations (in constant dollars) requested by OMB for agency $i$ in fiscal year $t$ as a proportion of the appropriations that agency received in the previous fiscal year; if an agency's OMB estimate in year $t$ is represented by $O M B_{i t}$, then $\triangle O M B_{i t}=$ $O M B_{i t} / C O N G_{i, r-1} ;^{7}$

$E_{t}=1$ during election years (the second session of each Congress), 0 otherwise; appropriations decisions concern the upcoming fiscal year, so appropriations considered by Congress during election years are for odd-numbered fiscal years;

$U_{t-1}=$ the average rate of unemployment during the first six months of the session of Congress in which appropriations for a given fiscal year are considered; for FY1965 this measure would thus register the unemployment rate during the first half of calendar year $1964 ;^{8}$

$I_{t-1}=$ the (annualized) percentage change in the Consumer Price Index during the first six months of the session of Congress in which appropriations for a given fiscal year are considered;

$D E M_{t}=$ the percentage of seats in the House held by Democrats;

TRANS $=1$ during years in which a Democratic president replaces a Republican, -1 when the transition goes from the Republicans to the Democrats, and 0 otherwise.

$\epsilon_{i t}=$ a randomly distributed error term.

Finally, in order to facilitate interpretation of the constant term, the unemployment, inflation, and partisan composition variables entered the equations as deviations from their mean values during this period. If the

${ }^{7}$ The instrumental variables estimate of $\triangle O M B_{i t}$ was created by imposing exclusionary restrictions-i.e., $\triangle O M B_{i t}$ was regressed on the same variables as was $\triangle C O N G_{i t}$ in equation 1 plus at least one additional variable - and the fitted values were used in equation 1 instead of $\triangle O M B_{i t}$. In this instance we actually specified several additional variables-dummy variables for the party of the president, for presidential election years, for war years (the Korean Conflict, FY1952-54, and Vietnam, FY1967-74), and the unemployment and inflation rates during the six months prior to the president's submission of the budget. This model was thus strictly overidentified. It should also be noted that the two-stage least squares program we employed made the requisite corrections to the estimated standard errors.

${ }^{8}$ As indicated earlier, research on economic conditions and voting behavior has generated persuasive evidence that voters respond retrospectively to past conditions, but that they tend to be myopic and have short memories. The short time frame used here thus assumes that at least in this respect members of Congress are like voters appear to be. (For a contrary view on this matter see Chappell and Keech, 1985.) 
data support our hypotheses, the signs of all coefficients except that of the inflation term should be positive. Results are reported in table 2.

\section{TABLE 2}

The Effects of Exogenous Economic and Political Variables upon Congressional Appropriations Decisions, FY1948-79 (2SLS Estimates)

\begin{tabular}{lclc}
\hline Variable & \multicolumn{3}{c}{ Variable } \\
\hline Constant & $.717^{* *}$ & Inflation & $-.552^{* *}$ \\
& $(.166)$ & & $(.225)$ \\
OMB Request $^{a}$ & $.307^{*}$ & Unemployment & $1.177^{*}$ \\
& $(.149)$ & & $(.601)$ \\
Proportion Democrats & $.271^{*}$ & Administration Transition & .035 \\
& $(.114)$ & & $(.022)$ \\
Election Year & $.028^{*}$ & & \\
$N=1038$ & $(.012)$ & & \\
\hline
\end{tabular}

Note: Data for the Census Bureau for fiscal years 1950, 1951, 1960, 1961, 1970, and 1971 were deleted because of the distortive effect of the constitutionally mandated decennial censuses.

${ }^{a}$ Endogenous variable.

$*=p<.05$.

${ }^{* *}=p<.01$.

The results of this analysis provide strong support for each of our hypotheses. All coefficients are in the predicted direction. Six are statistically significant, and the other (the coefficient of the transition term) falls just short of the conventional $p<.05$ level. Turning first to the economic variables, we see that during this period a 1 percent increase in the unemployment rate led, ceteris paribus, to a nearly 1.2 percent real increase in the appropriations awarded to these agencies in the subsequent fiscal year. This finding thus bears out Fenno's (1966) observation that economic downturns give rise to permissive moods toward spending. Conversely, a 1 percent increase in the Consumer Price Index has led Congress to reduce appropriations to these thirty-seven agencies by about 0.5 percent. This effect, however, could arise from mechanisms other than that which was hypothesized, that is, that Congress acts in a countercyclical fashion purposely to hold down government spending during inflationary periods. It could be that Congress actually seeks to maintain "current service levels" by keeping real dollar appropriations constant, but it is hampered by imperfect expectations of inflation rates. If Congress behaved as if it had "adaptive" expectations, for example, it 
would tend to underestimate the next fiscal year's inflation rate during periods of rising inflation (and thus "under-appropriate") and overestimate inflation (and thus "over-appropriate") during periods when inflation is slowing down. Whatever the case, in this realm Congress has definitely not increased real spending levels under the guise of compensating for inflation.

As hypothesized, appropriations decisions are also influenced by the electoral calendar. The estimated coefficient of the election year dummy indicates that, everything else being equal, these agencies received about 2.8 percent more in congressional election years than in nonelection years. Given the spate of recent studies questioning various elements of the Tufte (1978) scenario (McCallum, 1978; Golden and Poterba, 1980; Thompson and Zuk, 1983; Brown and Stein, 1982) the apparent impact here of election-year considerations is surprisingly strong.

It would be a mistake, however, to construe this evidence of an "electoral appropriations cycle" as a congressional source of political business cycles. Such cycles are alleged to result from more expansive fiscal and/or monetary policies which incumbent politicians pursue so as to generate a surging economy on election day. The agencies and programs analyzed in this study, though, are only a modest sample of those in existence. They do not include "big ticket" national defense and transfer payment programs, and so they account for only a small fraction of total government spending. Appropriations figures also reveal little about the actual timing of government expenditures, as the check-writing authority they represent can be for activities extending a number of years into the future. These data probably do suggest something about the willingness of incumbent politicians to influence the short-term course of the economy, but shed little light on their ability to do so.

Agency appropriations are also a function of the partisan composition of Congress. The .27 coefficient for this variable implies that it would require the election of around seventeen additional Republicans (i.e., a 4 percent increase in the share of seats held by that party) to lower these agencies' appropriations by 1 percent in real terms - a fairly modest effect. However, considering the context of the American Congress - an extremely decentralized legislature not noted for high levels of party discipline - this is impressive evidence that it does make a difference how many Democrats or Republicans are elected.

Finally, the signs of the endogenous $\triangle O M B_{i t}$ and administration transition terms were in the predicted positive direction, indicating that congressional appropriations decisions also accommodate the preferences of the president. ${ }^{\theta}$ Thus, if the president (by way of the OMB estimate) were

${ }^{\ominus}$ Estimation of the reduced form $\triangle O M B_{i t}$ equation strongly confirmed our expectations 
to ask for a 10 percent real increase in an agency's appropriations over the previous fiscal year, the agency will receive from Congress, ceteris paribus, a 3 percent increase. Within the typical range of $\mathrm{OMB}$ requests, the effect of this variable combined with the very large constant term $(.31+.72)$ implies a large degree of continuity in the size of agency budgets from year to year-or, if you will, that budgetary change is usually incremental. ${ }^{10}$

The coefficient of the transition term was surprisingly large; replacement of a Democratic president by a Republican, according to this estimate, leads Congress to appropriate about 3.5 percent less to a given agency than if the Democrat had remained in office. It is likely, however, that presidential influence in Congress is at a peak during the first year of an administration. The memory of the election is still fresh, and the president's popularity is likely to be as high as it is ever going to be. ${ }^{11}$

Finally, analysis of residuals indicated that these results were not compromised by potential econometric difficulties. First, the correlation between the residuals from one agency and those from another tended to be positive, but barely so (most of the Pearson $r$ statistics lay between .00 and .20 , and the number of associations which were statistically significant was only slightly larger than that which would be expected by chance). ${ }^{12}$ The other potential violation of the Gauss-Markov assumptions of concern here is serial correlation. Unfortunately, calculation of a DurbinWatson statistic is not appropriate with pooled data. What we did instead was to estimate equation 1 separately for the thirty-seven agencies in our sample with ordinary least squares and to calculate a DurbinWatson for each equation. These statistics registered little serial correla-

that the OMB submits larger budget estimates during Democratic administrations and that OMB budget estimates were held down during periods of war. In contrast to congressional appropriations, however, inflation and unemployment rates did not appear to affect OMB requests systematically, nor did the presence of a presidential election year. See Kiewiet and McCubbins (1984) for an extensive analysis of presidential (OMB) behavior in the appropriations process.

${ }_{10}$ The coefficient of the OMB term was considerably larger (approximately .8) when equation 2 was estimated with OLS regression. The OLS coefficients of the other exogenous variables, however, were all surprisingly close to the 2SLS coefficients reported in table 3.

${ }^{11}$ In a recent paper Rivers and Rose (1985) show that the president's success in getting his program through Congress is a function of his popularity. The model they estimated was similar to ours in that the president's actions (how many bills he introduced) and the actions of Congress (the percentage of bills they passed) were formulated as endogenous variables.

${ }^{12}$ As a final check on the specification of our model we reestimated it after including agency-specific dummy variables in both equations. Doing so resulted in only trivial changes in the coefficients of interest but did produce a tremendous increase in computational costs. 
tion; in only seven of the thirty-seven equations were they less than 1.5 or greater than 2.5. Given that neither pooling nor two-stage estimation induces any additional serial correlation, we believe that considerable confidence can be placed in these results.

In short, the evidence in table 2 indicates that major exogenous economic and political variables clearly influence congressional appropriations decisions. To be sure, the effects observed here are not massive; if incrementalism is simply taken to mean budgeting by "small steps" (Schick, 1982), our results pose no real challenge to this notion. If incrementalism is taken to imply that budgetary outcomes are merely the product of standard bureaucratic procedures and programmatic inertia, however, these results indicate otherwise.

\section{Analysis of Agency-Specific Hypotheses}

In several instances we predicted that the variables we are investigating would have more (or less) influence upon decisions regarding agencies which supply divisible, constituency-oriented benefits - especially public works agencies - than upon those regarding agencies which supply primarily indivisible benefits. To test these hypotheses we will estimate an equation which allows the coefficients of the explanatory variables to vary across the three subgroups of agencies. Quickly to summarize, we hypothesized that the tendency for Congress to treat agency requests more generously in election years is stronger for those agencies which supply divisible, constituency-oriented benefits - especially public works - than for agencies which supply largely indivisible benefits. We predicted the same pattern of results for unemployment. Although inflation might well affect agency budgets in a similar manner, there is also reason to believe that high rates of inflation do not alter the relative attractiveness of funding different types of agencies. We also reasoned that those agencies which supply divisible benefits-especially public works agencies - would be less subject to partisan controversy than line agencies whose benefits are relatively indivisible. Finally, we also felt it would be prudent to estimate separate constant terms for each different type of agency in order to determine whether or not they experienced different long-term budgetary growth rates.

There are a number of equivalent ways to specify a model which would test these hypotheses. The form we adopted was what is commonly referred to as a "switching regime" model (Maddala, 1977, p. 136), wherein a separate constant, unemployment, election year, and partisan composition coefficient is estimated for each of the three subsets of agencies. This equation, then, is as follows: 


$$
\begin{aligned}
\Delta \text { CONG }_{i t}=\alpha i & +\beta d+\delta p w+\gamma_{1}\left(i U_{t-1}\right)+\gamma_{2}\left(d U_{t-1}\right) \\
& +\gamma_{3}\left(p w U_{t-1}\right)+\gamma_{4}\left(i I_{t-1}\right)+\gamma_{5}\left(d I_{t-1}\right)+\gamma_{8}\left(p w I_{t-1}\right) \\
& +\gamma_{7}\left(i D E M_{t}\right)+\gamma_{8}\left(d D E M_{t}\right)+\gamma_{9}\left(p w D E M_{t}\right)+\gamma_{10}\left(i E_{t}\right) \\
& +\gamma_{11}\left(d E_{t}\right)+\gamma_{12}\left(p w E_{t}\right)+\gamma_{13} \Delta O M B_{i t}+\gamma_{14} \text { TRANS } \\
& +\epsilon_{i t},
\end{aligned}
$$

where $\triangle C O N G_{i t}, \triangle O M B_{i t}, D E M_{t}, U_{t-1}, I_{t-1}, E_{t}$, and $\epsilon_{t}$ are defined as before; $i=1$ if the $i$ th agency supplies indivisible benefits, 0 otherwise; $d=1$ if the $i$ th agency supplies divisible benefits (excluding public works), 0 otherwise; and $p w=1$ if the $i$ th agency supplies public works, 0 otherwise. Equation 2 thus does not specify an overall constant term.

If the data support our hypotheses, the coefficient of the unemployment term should be larger for agencies which supply divisible, constituency-oriented benefits than the coefficient for the indivisible benefit agencies, and should be largest for public works agencies $\left(\gamma_{3}\right.$ $\left.>\gamma_{2}>\gamma_{1}\right)$. The same ordering should hold for the unemployment terms $\left(\gamma_{12}>\gamma_{11}>\gamma_{10}\right)$ and, because the signs should be negative, for the inflation terms $\left(\gamma_{B}>\gamma_{5}>\gamma_{4}\right)$. The reverse order should hold for coefficients of the partisan composition terms $\left(\gamma_{8}>\gamma_{\theta}>\gamma_{10}\right)$. Results are reported below in table 3 .

A comparison of the results reported in table 3 with those from table 2 reveals that relaxing restrictions on the unemployment, inflation, party composition, and election-year terms did not perturb the estimated coefficients of the presidential influence variables; the $\triangle O M B_{i t}$ and administration transition terms are virtually identical across the two equations. Replacing the overall constant term with the three agency-type dummy variables was also of no consequence, as the coefficients of all three cluster around .7. Also as before, analysis of residuals revealed little evidence of either cross-sectional or serial correlation.

Our hypothesis regarding unemployment received an important degree of support in table 3: congressional response to high rates of joblessness was particularly strong with regard to those agencies which sponsor major construction projects. A 1 percent increase in the unemployment rate was associated with a nearly 5 percent increase in appropriations for these agencies in the subsequent fiscal year. The difference between this coefficient and both of the others was significant at the .05 level. Congress has thus reacted to high levels of joblessness in much the same manner as have governments going back to the pharaohs - with more and/or bigger public works projects (Garraty, 1978). On the other hand, there was not much difference between the coefficient for the other divisible benefit agencies and the coefficient for the indivisible benefit agencies (the latter was in fact marginally smaller than the former).

It also appears that agencies which supply relatively indivisible benefits 
TABLE 3

The Effects of Exogenous Economic and Political Variables upon Congressional Appropriations Decisions for Different Types of Federal Agencies, FY1948-79 (2SLS Estimates)

\begin{tabular}{lccc}
\hline & & TYPE OF AGENCY & \\
VARIABLE & $\begin{array}{c}\text { INDIVISIBLE } \\
\text { BENEFITS }\end{array}$ & $\begin{array}{c}\text { Divisible } \\
\text { BENEFITS }\end{array}$ & $\begin{array}{c}\text { PUBLIC } \\
\text { WorKS }\end{array}$ \\
\hline Constant & $.706^{* *}$ & $.745^{* *}$ & $.681^{* *}$ \\
Unemployment & $(.168)$ & $(.164)$ & $(.165)$ \\
& 1.086 & .312 & $5.731^{* *}$ \\
Inflation & $(.806)$ & $(.903)$ & $(1.822)$ \\
& $-.636^{*}$ & -.460 & -.374 \\
Proportion Democrats & $(.304)$ & $(.354)$ & $(.682)$ \\
& $.408^{* *}$ & $.312^{*}$ & $-.776^{*}$ \\
Election Year & $(.153)$ & $(.171)$ & $(.460)$ \\
& .028 & .028 & .033 \\
PresideNTIAL INFLUENCE VARIABLES & & & $(.040)$ \\
OMB Request & & & \\
& $(.018)$ & & \\
Administration Transition & $.305^{*}$ & & \\
$N=1038$ & $(.149)$ & & \\
\hline
\end{tabular}

Note: Data for the Census Bureau for fiscal years 1950, 1951, 1960, 1961, 1970, and 1971 were deleted because of the distortive effect of the constitutionally mandated decennial censuses.

a Coefficients of these variables are constrained to be the same across all types of agencies.

${ }^{b}$ Endogenous Variable.

${ }^{*}=p<.05$.

${ }^{* *}=p<.01$

bear more of the brunt of an inflation-induced "economy mood" than do those which supply relatively divisible benefits, and that the public works agencies are trimmed the least. Only the coefficient of the indivisible benefit agencies was significantly less than zero. Unfortunately, a consequence of estimating a separate coefficient for the three subsets of agencies in our sample is a larger standard error for each coefficient than for the single coefficient estimated in the previous analysis. The $t$ statistics are thus smaller, and the differences among these three coefficients are not significant. While these results are thus in keeping with our hypothesis, they are too fragile to place a great deal of confidence in them. 
Our hypothesis regarding the differential impact of election years upon the three different types of agencies did not fare very well at all. All three estimated coefficients were virtually identical to the single .028 election-year term in table 2. Findings concerning the partisan composition of the House were similar; although the coefficient for the indivisible benefit agencies was slightly larger than that for the divisible benefit agencies, this difference is far from being statistically significant. Probably the most surprising result is that of the party variable for public works agencies. While we had hypothesized agencies of this type to be particularly insensitive to the partisan composition of the House, they appear instead to be especially sensitive in the opposite direction than we had supposed. The negative significant coefficient indicates that appropriations for public works agencies actually increase, everything else held constant, as the number of Republicans increase. We are inclined not to make too much of this single coefficient. Perhaps, though, David Stockman's unflattering remarks about the robustness of his Republican colleagues' opposition to federal spending were even more justified than he had thought.

All in all, then, our decision to distinguish between different types of agencies was at least partially justified. Although our hypotheses concerning the differential effect of election years and party shares in the House were not borne out, our hypotheses concerning major economic variables did receive some empirical backing. The budgets of divisible benefit agencies appeared to hold up better during periods of inflation than the budgets of agencies which supply largely indivisible benefits. Congressional treatment of public works agencies, moreover, conformed nicely to the hypotheses derived from our electoral connection model, as appropriations awarded to these agencies were far more sensitive to the unemployment rate than were appropriations for other agencies.

The final issue we need to address concerns the generalizability of these results. As indicated earlier, the budgets of the agencies in this sample make up only a small fraction of total federal appropriations in a given fiscal year. But they do account for a sizable proportion of appropriations which are "controllable," and so we believe the results of our analyses can be generalized to all controllable expenditures. Any broader generalizations, however, are probably unwarranted. Estimation of our model on "uncontrollable" spending - for example, social welfare expenditures - might well have yielded a different pattern of results (Browning, 1983), as might estimation based upon units of analysis which differed greatly from individual federal agencies (Natchez and Bupp, 1973).

Finally, Brady and Morgan's (1983) study of appropriations reforms during the late nineteenth and early twentieth centuries suggests that the influence of various exogenous variables was probably different during 
earlier periods in history. We are confident, however, that nothing has happened since these data were gathered which would undermine the accuracy of the model's predictions of agency appropriations in the future. Indeed, we are currently planning to gather data from the first few Reagan fiscal years and put our confidence to the test. On the surface, however, the events of recent years seem entirely consistent with our model. In the year following Reagan's election, with inflation very high and unemployment still fairly low, Congress, which at that time contained a relatively large number of Republicans, acceded to a large share of the cuts Reagan proposed in the budgets of domestic agencies. A few years later, with inflation back under 5 percent and unemployment around 10 percent, a Congress containing twenty-six additional Democratic representatives was considerably more generous in its treatment of domestic agency budget requests.

\section{ConClusion}

The electoral connection model of congressional appropriations decisions examined in this paper was broadly informed by the assumption that members of Congress respond to the demands and exigencies of their environment in such a way so as to maximize their probability of reelection. Analyses of appropriations for thirty-seven federal agencies between fiscal years 1948 and 1979 strongly supported the hypotheses derived from this model. First, Congress has been more generous in awarding appropriations during election years than during nonelection years. Congressional appropriations decisions are also influenced by prevailing economic conditions. Higher unemployment leads to higher levels of appropriations, especially for public works agencies. Congress has consistently responded to high rates of inflation by holding down agency appropriations. Appropriations decisions also registered the effects of party differences: the larger the percentage of Democrats in the House of Representatives, the more funds agencies were appropriated. These results, then, identify another important policymaking domain where parties do matter (Hibbs, 1977; Cameron, 1978).

This study adds to a growing body of research which examines the impact of relevant exogenous variables upon budgetary decisions (Caldeira and Cowart, 1980; Padgett, 1981; Kamlet, Mowery, and Fischer, 1983; Mowery and Kamlet, 1982; Fischer and Kamlet, 1984; Winters and Reidenberg, 1983). As indicated earlier, the results of our analyses do no violence to notions of incrementalism, if this is simply taken to mean "budgeting by small steps." Our results, however, do challenge the incrementalist implication that budgetary outcomes are merely the product of standard bureaucratic operating procedures and programmatic inertia. 


\section{REFERENCES}

Arnold, Douglas (1979). Congress and the Bureaucracy. New Haven: Yale University Press.

Berman, Larry (1979). The Office of Management and Budget and the Presidency, 19211979. Princeton: Princeton University Press.

Brady, David, and Mark Morgan (1983). "Reforming the Structure of the House Appropriations Process: The Effects of the 1885 and 1919-1920 Reforms on Money Decisions." Paper presented at the Annual Meeting of the American Political Science Association, Chicago.

Brown, Thad, and Arthur Stein (1982). "The Political Economy of National Elections." Comparative Politics 14: 479-97.

Browning, Robert X. (1983). "Priorities, Programs, and Presidents: Assessing Patterns of Growth in U.S. Social Welfare Expenditures, 1949-1977." Paper presented at the Annual Meeting of the Midwest Political Science Association, Chicago.

Bueno de Mesquita, Bruce (1981). The War Trap. New Haven: Yale University Press.

Caldeira, Greg, and Andrew Cowart (1980). "Budgets, Institutions, and Change: Criminal Justice Policy in America." American Journal of Political Science 24: 413-38.

Cameron, David (1978). "The Expansion of the Public Economy: A Comparative Analysis." American Political Science Review 72: 1243-61.

Chappell, Henry W., Jr., and William R. Keech (1985). "A New View of Political Accountability for Economic Performance." American Political Science Review 78. Forthcoming.

Davis, Otto A., M. A. H. Dempster, and Aaron Wildavsky (1966). "A Theory of the Budgetary Process." American Political Science Review 60: 529-47.

(1974). "Toward a Predictive Theory of Government Expenditures: U.S. Domestic Appropriations." British Journal of Political Science 4: 419-52.

Fair, Ray (1978). "The Effect of Economic Events on Votes for President." Review of Economics and Statistics 60: 159-73.

Fenno, Richard F. (1966). The Power of the Purse: Appropriations Politics in Congress. Boston: Little, Brown.

(1978). Homestyle: House Members in Their Districts. Boston: Little, Brown.

Ferejohn, John (1974). Pork Barrel Politics. Stanford: Stanford University Press.

Fiorina, Morris P. (1974). Representatives, Roll Calls, and Constituencies. Boston: Lexington.

(1977). Congress: Keystone of the Washington Establishment. New Haven: Yale University Press.

Fischer, G., and M. Kamlet (1984). "Explaining Presidential Priorities: The Competing Aspiration Levels Model of Macrobudgetary Decision Making." American Political Science Review 77: 356-71.

Garraty, John (1978). Unemployment in History. New York: Harper and Row.

Golden, David, and James Poterba (1980). "The Price of Popularity: The Political Business Cycle Reexamined." American Journal of Political Science 24: 696-714.

Hibbs, Douglas (1977). "Political Parties and Macroeconomic Policy." American Political Science Review 71: 1467-87.

Jacobson, Gary, and Samuel Kernell (1981). Strategy and Choice in Congressional Elections. New Haven: Yale University Press.

Kamlet, M., D. Mowery, and G. Fischer (1983). "Modelling Budgetary Tradeoffs: An Analysis of Congressional Macrobudgetary Priorities, the Impact of the Congressional Budget Act, and the Reagan Revolution." Paper presented at the Annual Meeting of the Midwest Political Science Association, Chicago. 
Kiewiet, D. Roderick (1983). Macroeconomics and Micropolitics. Chicago: University of Chicago Press.

Kiewiet, D. Roderick, and Mathew McCubbins (1984). "Congress, the President, and the Appropriations Process." Legislative Studies Quarterly. Forthcoming.

Kramer, Gerald (1971). "Short-Term Fluctuations in U.S. Voting Behavior, 1896-1964." American Political Science Review 65: 131-43.

Lindblom, C. E. (1961). "Decision-Making in Taxation and Expenditures." In C. E. Lindblom, Public Finance: Needs, Sources, and Utilization. Princeton: Princeton University Press.

McCallum, Bennet (1978). “The Political Business Cycle: An Empirical Test." Southern Economic Journal 44: 504-15.

McConnell, Grant (1966). Private Power and American Democracy. New York: Alfred A. Knopf.

McCubbins, Mathew (1984). "Regulating the Regulators: A Theory of Legislative Delegation." Working Paper on Institutional Design and Public Policy, Department of Government, University of Texas.

McCubbins, Mathew, and Terry Sullivan (1984). "Constituency Influence on Legislative Policy Choice." Quality and Quantity. Forthcoming.

Maddala, G. S. (1977). Econometrics. New York: McGraw-Hill.

Mayhew, David (1974). Congress: The Electoral Connection. New Haven: Yale University Press.

Mowery, David, and Mark Kamlet (1982). “Coming Apart: Fiscal and Budgetary Policy Processes in the Johnson Administration." Public Budgeting and Finance 11: 16-34.

Natchez, Peter, and Irving Bupp (1973). "Policy and Priority in the Budgetary Process." American Political Science Review 67: 951-63.

Nordhaus, William (1975). "The Political Business Cycle." Review of Economic Studies 42: 169-89.

Olson, Mancur (1965). The Logic of Collective Action. Cambridge: Harvard University Press.

Padgett, John (1981). "Hierarchy and Ecological Control in Federal Budgetary Decision Making." American Journal of Sociology 87: 75-129.

Piachaud, David (1978). "Inflation and the Income Distribution." In Fred Hirsch and John Goldthorpe (eds.), The Political Economy of Inflation. Cambridge: Harvard University Press.

Poole, Keith, and Howard Rosenthal (1983). “The Polarization of American Politics." Unpublished ms. Carnegie-Mellon University.

Rivers, Douglas, and Nancy Rose (1985). "Passing the Presidents' Program: Public Opinion and Presidential Influence in Congress." American Journal of Political Science 29. Forthcoming.

Schick, Allen (1980). Congress and Money. Washington, D.C.: The Urban Institute. (1982). "The Politics of Budgeting: Can Incrementalism Survive in a Decremental Age?" Paper presented at the Annual Meeting of the American Political Science Association, Denver.

Shepsle, Kenneth (1983). "The Failure of Congressional Budgeting." Social Science and Modern Society 20: 4-10.

Shepsle, Kenneth, and Barry Weingast (1984). "Political Solutions to Market Problems." American Political Science Review 78: 417-34.

Simon, Herbert (1957). "A Behavioral Model of Rational Choice." In H. Simon (ed.), Models of Man. New York: John Wiley.

Thompson, William, and Gary Zuk (1983). “American Elections and the International 
Electoral-Economic Cycle: A Test of the Tufte.Hypothesis." American Journal of Political Science 27: 464-84.

Tufte, Edward R. (1978). Political Control of the Economy. Princeton: Princeton University Press.

Weingast, Barry, Kenneth Shepsle, and Christopher Johnson (1981). "The Political Economy of Benefits and Costs: A Neoclassical Approach to the Politics of Distribution." Journal of Political Economy 89: 642-64.

Wildavsky, Aaron (1964). The Politics of the Budgetary Process. Boston: Little, Brown. Little, Brown. (1975). Budgeting: A Comparative Theory of the Budgetary Process. Boston:

Winters, Richard, and Joel Reidenberg (1983). “Appropriations Politics and the Political Business Cycle." Unpublished ms. Dartmouth College.

\section{Appendix: Data Sources}

Presidential budget requests (in the form of OMB estimates) and final appropriations figures are reported in the Annual Senate Document $A p$ propriations, Budget Estimates, Etc., the section entitled "Itemized Comparisons of Budget Estimates and Appropriations Arranged by Senate Acts."

The deflator used to convert the appropriations and estimates figures into constant dollars was the Implicit Price Deflator for Federal Government Purchases of Goods and Services. The time series for this deflator was taken primarily from The National Income and Product Accounts of the United States, 1929-74, Statistical Tables. Data after that date are taken from monthly issues of the Survey of Current Business. Both are published by the Bureau of Economic Analysis, U.S. Department of Commerce.

The unemployment and the Consumer Price Index figures were taken from issues of the Monthly Labor Review, Bureau of Labor Statistics, U.S. Department of Labor.

These data are available upon request. 